\title{
Perilaku Berisiko Sebagai Faktor Penyebab Kecelakaan Pada Pengemudi Sepeda Motor Komersial: Systematic Review
}

\author{
Ahmad Afif Mauludi*1, Zulkifli Djunaidi ${ }^{2}$, Luthfi Saiful Arif ${ }^{3}$ \\ ${ }^{12}$ Departemen Magister Keselamatan dan Kesehatan Kerja \\ Fakultas Kesehatan Masyarakat, Universitas Indonesia \\ Kampus Baru Universitas Indonesia Depok 16424 \\ ${ }^{3}$ Peneliti Independen \\ E-mail: *ahmad.afif81@ui.ac.id
}

Received 30-03-2021; Reviewed 12-04-2021; Accepted 16-04-2021

Journal Homepage: http://ktj.pktj.ac.id/index.php/ktj

DOI: $10.46447 / \mathrm{ktj} . \mathrm{v} 8 \mathrm{i} 1.307$

\begin{abstract}
Abstrak
Transportasi menjadi hal yang penting dalam mobilitas di zaman modern dan jasa sepeda motor komersial menjadi pilihan utama pengguna jalan di Indonesia. Terlepas dari banyaknya keuntungan tersebut pengemudi sepeda motor komersial memiliki ancaman keselamatan dengan tingginya angka kecelakaan sepeda motor. Kecelakaan tersebut sebagian besar diakibatkan oleh perilaku berisiko yang dilakukan oleh pengemudi itu sendiri. Penelitian merupakan sebuah tinjauan pustaka sistematis, yang bertujuan untuk mengkaji bentuk perilaku berisiko saat berkendara, faktor-faktor yang mempengaruhinya dan bagaimana kontribusinya dalam kejadian kecelakaan lalu lintas pada pengemudi sepeda motor komersial dari berbagai penelitian. Berdasarkan hasil systematic review, perilaku berisiko pengemudi sepeda motor komersial signifikan berhubungan dengan kejadian kecelakaan memiliki bentuk, berkendara dalam pengaruh alkohol, merokok saat mengemudi, penggunaan lampu kendaraan yang tidak sesuai, penggunaan handphone saat mengemudi, jumlah penumpang yang melebihi kapasitas, pelanggaran marka jalan, menyalip secara berbahaya, penggunaan lampu indikator yang tidak sesuai, pelanggaran kecepatan, pelanggaran rambu dan sinyal lalu lintas. Perilaku berisiko saat mengemudi tersebut dipengaruhi oleh berbagai faktor, diantaranya persepsi keselamatan dan risiko berkendara, kondisi jalan, tuntutan ekonomi, kebiasaan merokok, umur, tingkat pendidikan, pengalaman kecelakaan, pelatihan dan pengalaman mengemudi. Untuk mengurangi tingkat kecelakaan pada pengemudi sepeda motor komersial, diperlukan penyediaan fasilitas peningkatan edukasi dan pelatihan keselamatan oleh pihak penyedia aplikasi atau pemerintah.
\end{abstract}

Kata Kunci: Perilaku Berisiko, Sepeda Motor Komersial, Kecelakaan, Systematic Review 


\section{PENDAHULUAN}

Di zaman modern ini transportasi memiliki peran yang penting untuk mobilitas, terutama di wilayah perkotaan. Sebagian besar masyarakat Indonesia $(81,78 \%)$ memilih sepeda motor dibanding jenis kendaraan lain sebagai mode transportasinya (BPS RI, 2020). Sepeda motor dinilai memiliki kelebihan seperti dapat menempuh jarak jauh dengan waktu cepat, terhindar dari kemacetan lalu lintas (Djaleha, 2018) dan ekonomis (Ali dkk., 2018), sehingga banyak konsumen yang memilih untuk menggunakan layanan pengemudi komersial sepeda motor sebagai moda transportasinya. Jasa sepeda motor komersial telah dikenal sejak tahun 1960-an oleh masyarakat Indonesia, terutama di kota besar seperti Jakarta, sebagai jasa pengantaran penumpang, atau dikenal dengan istilah ojek (Fauziah, 2017). Namun seiring perkembangan teknologi, diluncurkan jasa sepeda motor komersial berbasis aplikasi atau ojek online, pertama kali pada akhir tahun 2010 (Gojek, 2021). Saat ini layanan pengemudi sepeda motor digunakan untuk melakukan berbagai macam jasa pengantaran, yaitu pengantaran penumpang, makanan serta barang dan jasa (Gojek, 2021b; Grab ID, 2021). Pada mulanya penggunaan sepeda motor komersial sulit untuk mendapatkan izin legal, karena tidak secara tegas diatur dalam perundangan terkait lalu lintas dan angkutan jalan (Djaleha, 2018). Namun saat ini Pemerintah telah mengeluarkan peraturan terkait dengan jasa layanan menggunakan sepeda motor roda dua, terutama yang menggunakan perantara aplikasi telepon pintar, melalui PM 12 Tahun 2019 tentang Perlindungan Keselamatan Pengguna Sepeda Motor yang Digunakan untuk Kepentingan Masyarakat (Kementerian Perhubungan, 2019). Walau banyak memiliki kelebihan, pengendara motor roda dua memiliki risiko yang sangat tinggi terhadap kecelakaan lalu lintas (Wicaksono, 2019). Masalah kecelakaan lalu lintas menjadi suatu hal yang vital yang perlu dilakukan kajian terhadapnya, baik mengenai penyebab, akibat, dan penanganannya (Oktopianto et al., 2021).

Tahun 2019, kecelakaan lalu lintas di Indonesia mengalami kenaikan rata-rata 4,87 persen per tahun, dengan jumlah kecelakaan mencapai 116.411 kasus, diikuti dengan kenaikan korban meninggal dunia dan luka ringan, sebesar 1,41 persen dan 6,26 persen (BPS RI, 2020). Kecelakaan lalu lintas yang menyebabkan kematian di negara berkembang, termasuk Indonesia, terbesar dialami oleh pengendara motor roda-2 (WHO, 2018). Pada tahun 2018, kecelakaan lalu lintas yang melibatkan sepeda motor mencapai 73,49 persen dari total 196.457 kejadian, dengan penyebab utama berkaitan dengan perilaku berisiko dari pengemudi, yaitu penggunaan helm, melawan arus, penggunaan handphone saat berkendara, melanggar batas kecepatan dan berkendara dalam pengaruh minuman beralkohol (Korlantas Polri, 2019). Hal tersebut senada dengan penelitian Cooper (1999), dimana hasil penelitian tersebut menyatakan bahwa kecelakaan terjadi 85\% - $90 \%$ karena perilaku berisiko. Hasil penelitian tersebut juga didukung oleh teori kecelakaan Heinrich (1931), yang menyebutkan bahwa $88 \%$ kecelakaan disebabkan oleh perilaku berisiko. Pada penelitian sebelumnya, yang dilakukan pada pengemudi roda dua, perilaku berisiko pada saat mengemudi dipengaruhi oleh persepsi terhadap risiko keselamatan pengemudi (Pinchumpholsang, 2020; Nguyen-Phuoc dkk., 2020c) dan peningkatan persepsi terhadap risiko keselamatan merupakan salah 
satu upaya untuk menurunkan perilaku berisiko pada saat mengemudi (Nguyen-Phuoc dkk., 2020c). Selain itu, secara teori, perilaku dapat dipengaruhi oleh faktor internal dan eksternal (Maze, 2019). Faktor internal termasuk intensi/niat, jenis kelamin, kepribadian, kemampuan, mood/emosi, nilai/kepercayaan, norma subjektif, pengalaman, pengetahuan, persepsi risiko, sikap, tingkat pendidikan dan usia. Sedangkan faktor eksternal dapat berasal dari agama, ekonomi, media, pendidikan dan sosial budaya (Fishbein dan Ajzen, 2011). Tujuan penulisan artikel ini adalah untuk mengkaji bentuk perilaku berisiko saat berkendara, faktor-faktor yang mempengaruhinya dan bagaimana kontribusinya dalam kejadian kecelakaan lalu lintas pada pengemudi sepeda motor komersial dari berbagai penelitian.

\section{METODE}

Studi ini menggunakan metode tinjauan pustaka sistematik atau systematic review. Systematic review merupakan salah satu metode tinjauan pustaka yang secara jelas memformulasikan pertanyaan penelitian dan menggunakan metode yang sistematis untuk mengidentifikasi, memilih dan menilai secara kritis studi yang relevan, serta mengumpulkan dan menganalisis data yang dimasukkan ke dalam tinjauan pustaka, sehingga proses tinjauan pustaka memiliki metode yang jelas, komprehensif, transparan dan dapat dilakukan kembali oleh orang lain (Siddaway dkk., 2018). Studi ini menggunakan alur skema yang diadopsi dari Preferred Reporting Items for Systematic Reviews and Meta-Analyses (PRISMA) (Moher dkk., 2009). Langkah pertama adalah identifikasi semua artikel tentang perilaku berkendara pada pengemudi sepeda motor komersial, faktor-faktor yang mempengaruhinya dan kontribusinya pada kecelakaan lalu lintas (gambar 1). Database yang digunakan dalam pencarian berupa database elektronik, yaitu ScienceDirect, Taylor and Francis Online, Scopus dan Google Scholar. Setelah identifikasi, dilakukan penyaringan artikel melalui beberapa tahap. Secara berurutan dilakukan penyaringan berdasarkan kriteria inklusi dan eksklusi; penyaringan judul dan abstrak; penyaringan duplikasi; penyaringan tujuan metode dan pertanyaan penelitian. Artikel yang terpilih dianalisis berdasarkan komponen $\mathrm{PI}(\mathrm{E}) \mathrm{COS}$ (population, intervention/exposure, control/comparison, outcome dan study design) (CRD, 2009).

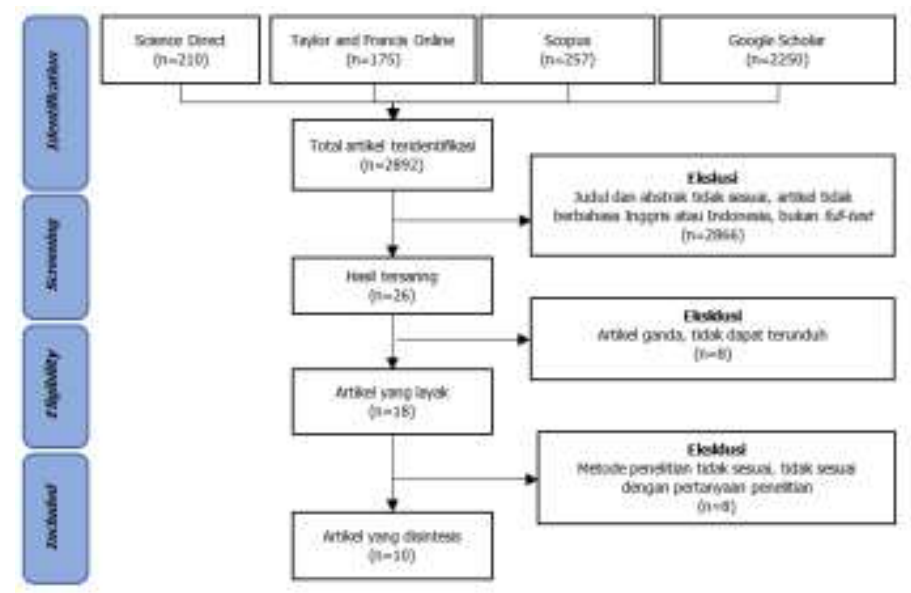

Gambar 1. Alur Skema Pengumpulan Artikel Penelitian 
Pencarian artikel dilakukan pada bulan Februari - Maret 2021 dan dibatasi hanya memasukkan artikel yang terbit pada tahun 2011-2021, serta memilih artikel dengan desain studi cross-sectional yang relevan dengan pertanyaan penelitian. Artikel menggunakan Bahasa Inggris dan Indonesia. Kata kunci yang digunakan dalam pencarian pustaka adalah motorcycle taxi/commercial motorcycle, driver/rider dan behavior/behavior. 


\section{HASIL DAN PEMBAHASAN}

\section{Hasil}

Hasil pencarian pustaka menggunakan kata kunci yang disusun menggunakan operator pencarian Boolean menjadi ("Motorcycle Taxi" OR "Commercial Motorcycle") AND (Driver OR Rider) AND (Behavior OR Behaviour). Didapatkan total 2892 artikel yang teridentifikasi, namun setelah proses penyaringan dan penilaian kelayakan terdapat hanya 10 artikel yang membahas perilaku berisiko pada pengendara motor roda dua komersial dan layak masuk ke dalam penelitian. Hasil sintesis artikel yang masuk dalam penelitian dapat dilihat pada tabel 1.

Tabel 1. Sintesis Artikel Penelitian

\begin{tabular}{|c|c|c|c|c|c|}
\hline $\begin{array}{c}\text { Penulis/ } \\
\text { Negara }\end{array}$ & Tujuan Penelitian & $\begin{array}{c}\text { Desain } \\
\text { Penelitian }\end{array}$ & $\begin{array}{c}\text { Sampel } \\
\text { Penelitian }\end{array}$ & Variabel & Hasil Penelitian \\
\hline $\begin{array}{l}\text { (Wankie dkk., } \\
\text { 2021)/ } \\
\text { Kamerun }\end{array}$ & $\begin{array}{l}\text { Untuk mengetahui } \\
\text { prevalensi } \\
\text { kecelakaan sepeda } \\
\text { motor komersial dan } \\
\text { faktor penyebabnya }\end{array}$ & $\begin{array}{c}\text { Cross- } \\
\text { Sectional }\end{array}$ & $\begin{array}{l}\text { Sampel } \\
\text { penelitian } \\
\text { merupakan } 552 \\
\text { Pengemudi } \\
\text { sepeda motor } \\
\text { komersial }\end{array}$ & $\begin{array}{l}\text { - } \text { Demografi: tingkat pendidikan, jenis } \\
\text { kelamin, usia, status pernikahan, } \\
\text { Pengalaman mengemudi } \\
\text { - Kebiasaan merokok } \\
\text { - Kebiasaan meminum alkohol } \\
\text { - } \text { Durasi tidur malam dan siang } \\
\text { - Status kepemilikan kendaraan } \\
\text { - Kepemilikan Surat Izin Mengemudi (SIM) } \\
\text { - } \text { S Surat Tanda Nomor Kendaraan (STNK) } \\
\text { - } \text { Pelatihan } \\
\text { - } \text { Waktu operasi } \\
\text { - Pengalaman kecelakaan } \\
\text { - } \text { Kondisi jalan } \\
\text { - Perilaku berkendara: ADU, NoP, SPD }\end{array}$ & 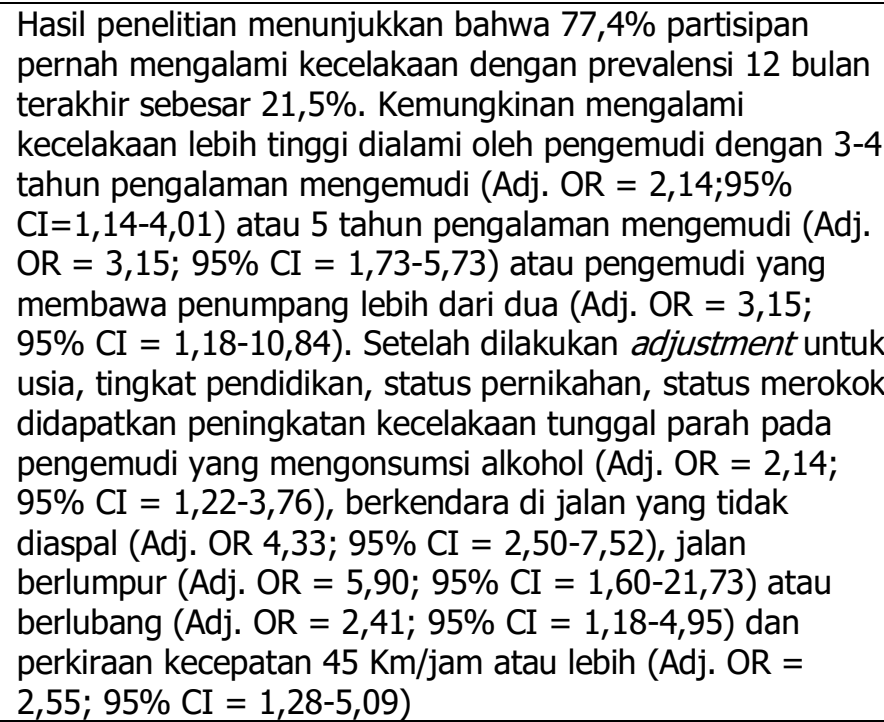 \\
\hline $\begin{array}{l}\text { (Kiwango } \\
\text { dkk., 2020)/ } \\
\text { Tanzania }\end{array}$ & $\begin{array}{l}\text { Untuk mengetahui } \\
\text { hubungan antara } \\
\text { persepsi risiko } \\
\text { terhadap perilaku } \\
\text { tidak aman saat } \\
\text { berkendara dengan } \\
\text { perilaku berkendara }\end{array}$ & $\begin{array}{l}\text { Cross- } \\
\text { Sectional }\end{array}$ & $\begin{array}{l}\text { Sampel } \\
\text { penelitian } \\
\text { merupakan } 399 \\
\text { pengendara } \\
\text { sepeda motor } \\
\text { komersial }\end{array}$ & $\begin{array}{l}\text { - } \text { Demografi: usia, pendidikan, status } \\
\text { - } \text { pernikahan, pengalaman mengemudi } \\
\text { - } \text { Purasi jam kerja } \\
\text { - } \text { Pelatihan mengemudi } \\
\text { - } \text { Kepemilikan SIM } \\
\text { - } \text { Pengalaman \& Keparahan Kecelakaan } \\
\end{array}$ & $\begin{array}{l}\text { Hasil penelitian menunjukkan bahwa } 60 \% \text { responden } \\
\text { mengemudi dengan perilaku tidak aman. Perilaku tidak } \\
\text { aman saat mengemudi (Adj. PR }=1.7 ; 95 \% \text { CI } 1.3-2.2 \text { ) } \\
\text { berhubungan dengan rendahnya persepsi terhadap bahaya } \\
\text { dari perilaku mengemudi tidak aman diantara pengemudi } \\
\text { motor. Semakin tinggi penghasilan (Adj. PR }=1.6 ; 95 \% \mathrm{CI} \\
1.2-2.0 \text { ), semakin tinggi kemungkinan memiliki persepsi }\end{array}$ \\
\hline
\end{tabular}




\begin{tabular}{|c|c|c|c|c|c|}
\hline $\begin{array}{c}\text { Penulis/ } \\
\text { Negara }\end{array}$ & Tujuan Penelitian & $\begin{array}{c}\text { Desain } \\
\text { Penelitian }\end{array}$ & $\begin{array}{c}\text { Sampel } \\
\text { Penelitian }\end{array}$ & Variabel & Hasil Penelitian \\
\hline & $\begin{array}{l}\text { yang dilaporkan } \\
\text { pada pengemudi } \\
\text { roda dua komersial }\end{array}$ & & & $\begin{array}{l}\text { - } \text { Perilaku berkendara: ADU, DSB, HLU, } \\
\text { HPU, HU, NoP, TRV } \\
\text { - } \text { Persepsi Risiko }\end{array}$ & risiko yang rendah terhadap perilaku tidak aman. \\
\hline $\begin{array}{l}\text { (Vissoci dkk., } \\
\text { 2020)/ } \\
\text { Rwanda }\end{array}$ & $\begin{array}{l}\text { Untuk } \\
\text { menggambarkan } \\
\text { perilaku keselamatan } \\
\text { diantara pengemudi } \\
\text { roda dua komersial }\end{array}$ & $\begin{array}{l}\text { Cross- } \\
\text { Sectional }\end{array}$ & $\begin{array}{l}\text { Sampel } \\
\text { penelitian } \\
\text { merupakan } 609 \\
\text { pengemudi } \\
\text { taksi sepeda } \\
\text { motor }\end{array}$ & $\begin{array}{l}\text { - Demografi: usia, pengalaman } \\
\text { - } \text { Dengemudi } \\
\text { - Jam mulai dan berhenti kerja } \\
\text { - Pengalaman \& Keparahan Kecelakaan } \\
\text { - Perilaku berkendara: HLU, HU, xPBL }\end{array}$ & $\begin{array}{l}\text { Hasil penelitian menunjukkan bahwa } 38,7 \% \text { pengemudi } \\
\text { pernah mengalami kecelakaan, dimana lebih dari setengah } \\
(n=134,56,8 \%) \text { mengalami cedera. Diantara semua } \\
\text { cedera, } 38,8 \%(n=52) \text { diantaranya harus dirawat di rumah } \\
\text { sakit dan } 14,2 \%(n-19) \text { mengalami disabilitas. Pengendara } \\
\text { motor dilaporkan } 100 \% \text { memiliki perilaku selalu } \\
\text { menggunakan helm, } 99 \% \text { selalu menggunakan tali dagu, } \\
98,8 \% \text { memiliki penumpang yang selalu menggunakan } \\
\text { helm. Terdapat hubungan antara pengalaman kecelakaan } \\
\text { dan kepercayaan bahwa helm }(p=0,08) \text { dan tali dagu } \\
(p=0,05) \text { mengurangi risiko dari kecelakaan. }\end{array}$ \\
\hline $\begin{array}{l}\text { (Nguyen- } \\
\text { Phuoc dkk., } \\
\text { 2020a)/ } \\
\text { Vietnam }\end{array}$ & $\begin{array}{l}\text { Untuk } \\
\text { menginvestigasi } \\
\text { insiden perlaku } \\
\text { mengemudi yang } \\
\text { berisiko dan } \\
\text { hubungannya } \\
\text { dengan karakteristik } \\
\text { pengemudi dan } \\
\text { kejadian kecelakaan }\end{array}$ & $\begin{array}{l}\text { Cross- } \\
\text { Sectional }\end{array}$ & $\begin{array}{l}\text { Sampel } \\
\text { penelitian } \\
\text { merupakan } 602 \\
\text { pengemudi } \\
\text { taksi sepeda } \\
\text { motor berbasis } \\
\text { aplikasi }\end{array}$ & $\begin{array}{ll}\text { - } & \text { Demografi: usia, pekerjaan } \\
& \text { (pelajar/bukan pelajar), tingkat } \\
& \text { pendidikan } \\
\text { - } & \text { Tipe pengemudi (migrant \& non-migrant) } \\
\text { - } & \text { Status pekerjaan (part-time/full-time) } \\
\text { - } & \text { Persepsi kecukupan penghasilan } \\
\text { - } & \text { Durasi jam kerja } \\
\text { - } & \text { Pengalaman \& keparahan kecelakaan } \\
\text { - } & \text { Perilaku berkendara: ADU, DSB, HPU, } \\
& \text { HU, NoP, RMV, RO, SN, SPD, TSV }\end{array}$ & $\begin{array}{l}\text { Hasil penelitian menunjukkan bahwa penggunaan telepon } \\
\text { genggam (HP) saat mengemudi merupakan perilaku } \\
\text { berisiko ( } 52 \%) \text { yang paling sering dilakukan diantara } \\
\text { pengemudi taksi roda dua berbasis aplikasi, diikuti dengan } \\
\text { SN ( } 31 \%) \text {, RMV ( } 25 \%) \text {, SPD ( } 21 \%) \text {, TSV (19\%), NoP } \\
(17 \%) \text {. Selain itu pengemudi yang merupakan pelajar, atau } \\
\text { yang bekerja lebih dari } 50 \text { jam per minggu, memiliki } \\
\text { kecenderungan untuk melakukan perilaku mengemudi yang } \\
\text { berisiko. Model regresi logistik biner menunjukkan bahwa } \\
\text { SN, NoP dan SB memiliki hubungan yang signifikan dengan } \\
\text { kejadian kecelakaan aktif/jatuh. Insiden perilaku berisiko } \\
\text { saat mengemudi memiliki hubungan dengan pengalaman } \\
\text { kecelakaan, ditemukan lebih rendah pada pengemudi roda } \\
\text { dua komersial berbasis aplikasi dibanding pengemudi roda } \\
\text { dua lainnya, namun masih diperlukan peningkatan edukasi } \\
\text { dan pelatihan keselamatan jalan oleh pihak penyedia } \\
\text { aplikasi. }\end{array}$ \\
\hline (Nguyen- & Untuk & Cross- & Sampel & - Demografi: usia, jenis kelamin, status & Hasil penelitian menunjukkan bahwa pengemudi yang \\
\hline
\end{tabular}




\begin{tabular}{|c|c|c|c|c|c|}
\hline $\begin{array}{c}\text { Penulis/ } \\
\text { Negara }\end{array}$ & Tujuan Penelitian & $\begin{array}{c}\text { Desain } \\
\text { Penelitian }\end{array}$ & $\begin{array}{c}\text { Sampel } \\
\text { Penelitian }\end{array}$ & Variabel & Hasil Penelitian \\
\hline $\begin{array}{l}\text { Phuoc dkk., } \\
\text { 2020b)/ } \\
\text { Vietnam }\end{array}$ & $\begin{array}{l}\text { mengeksplorasi } \\
\text { dampak dari gaya } \\
\text { hidup tidak sehat } \\
\text { terhadap perlaku } \\
\text { berisiko saat } \\
\text { mengemudi pada } \\
\text { pengemudi taksi } \\
\text { roda dua berbasis } \\
\text { aplikasi }\end{array}$ & Sectional & $\begin{array}{l}\text { penelitian } \\
\text { merupakan } 602 \\
\text { pengemudi } \\
\text { taksi sepeda } \\
\text { motor berbasis } \\
\text { aplikasi }\end{array}$ & $\begin{array}{l}\text { pernikahan, pekerjaan (pelajar/bukan } \\
\text { pelajar), tingkat pendidikan } \\
\text { - } \text { Pengalaman mengemudi } \\
\text { - } \text { Tipe Pengemudi (migrant \& non-migrant) } \\
\text { - } \text { Status pekerjaan } \\
\text { - Persepsi kecukupan penghasilan } \\
\text { - } \text { Tipe sepeda motor } \\
\text { - } \text { Durasi jam kerja } \\
\text { - Gaya hidup tidak sehat: merokok dan } \\
\text { - } \text { minum alkohol } \\
\text { Perilaku berkendara: ADU, DSB, HPU, } \\
\text { HU, NoP, RMV, RO, SN, SPD, TSV }\end{array}$ & $\begin{array}{l}\text { merokok dan minum alkohol secara reguler memiliki } \\
\text { kecenderungan untuk melakukan perilaku berkendara } \\
\text { berisiko ADU (Adj. OR }=18.61,95 \% \mathrm{CI}, \mathrm{p}<0.001 \text { ) dan DSB } \\
\text { (Adj. OR }=9.02,95 \% \mathrm{CI}, \mathrm{p}<0.01 \text { ). Selain itu hasil } \\
\text { penelitian juga mengindikasikan bahwa pengemudi yang } \\
\text { terkadang merokok memiliki kecenderungan untuk tidak } \\
\text { menggunakan helm saat berkendara (Adj. OR }=2.55, \mathrm{p} \\
<0.01 \text { ). Sedangkan kebiasaan merokok berhubungan } \\
\text { dengan ADU dan HU dan Sebagian besar perilaku berisiko } \\
\text { saat mengemudi berhubungan dengan kebiasaan minum } \\
\text { alkohol. Terdapat hubungan yang signifikan antara } \\
\text { merokok/minum alkohol dengan perilaku risiko lainnya saat } \\
\text { mengemudi. }\end{array}$ \\
\hline $\begin{array}{l}\text { (Konlan dkk., } \\
\text { 2020)/Ghana }\end{array}$ & $\begin{array}{l}\text { Untuk melihat } \\
\text { prevalensi dan pola } \\
\text { dari kecelakaan } \\
\text { sepeda motor pada } \\
\text { pengemudi sepeda } \\
\text { motor komersial }\end{array}$ & $\begin{array}{l}\text { Cross- } \\
\text { sectional }\end{array}$ & $\begin{array}{l}\text { Sampel } \\
\text { penelitian } \\
\text { merupakan } 144 \\
\text { pengemudi } \\
\text { sepeda motor } \\
\text { komersial }\end{array}$ & $\begin{array}{l}\text { - } \text { Demografi: usia, jenis kelamin, status } \\
\text { - } \text { Kernikahan, tingkat pendidikan } \\
\text { - } \text { Pengalaman \& keparahan kecelakaan } \\
\text { - } \text { Kepemilikan SIM \& STNK } \\
\text { - } \text { Peraturan lalu lintas } \\
\text { - } \\
\text { Perilaku berkendara: HU, RMV, SPD, TSV }\end{array}$ & $\begin{array}{l}\text { Hasil penelitian menunjukkan prevalensi kecelakaan lalu } \\
\text { lintas di tempat penelitian adalah } 64 \% \text {. Pengemudi sepeda } \\
\text { motor }(74 \%) \text { dilaporkan terlibat dalam kecelakaan selama } \\
\text { satu tahun terakhir. Kecelakaan pengemudi sepeda motor } \\
\text { tersebut dikarenakan melaju dengan kecepatan tinggi } \\
(31,5 \%) \text {, jalan rusak }(23,3 \%), \text { tabrakan dengan } \\
\text { pengendara sepeda motor lain }(50,7 \%) \text { dan jalan licin } \\
(24,7 \%) \text {. Sebagian besar responden }(63 \%) \text { mengalami } \\
\text { kecelakaan setidaknya sekali. Konsumsi minuman } \\
\text { beralkohol memiliki kecenderungan terhadap kecelakaan } \\
(34,2 \%) \text { daripada pengemudi yang tidak mengonsumsi } \\
\text { alkohol }(29,8 \%)(p<0,05) \text {. }\end{array}$ \\
\hline $\begin{array}{l}\text { (Shin dkk., } \\
\text { 2018)/Korea }\end{array}$ & $\begin{array}{l}\text { Untuk } \\
\text { menginvestigasi } \\
\text { karakteristik dari } \\
\text { kecelakaan dan } \\
\text { pelanggaran lalu lalu } \\
\text { lintas yang dilakukan } \\
\text { oleh kurir } \\
\text { pengemudi sepeda } \\
\text { motor. }\end{array}$ & $\begin{array}{l}\text { Cross- } \\
\text { sectional }\end{array}$ & $\begin{array}{l}\text { Sampel } \\
\text { penelitian } \\
\text { merupakan } 671 \\
\text { kurir } \\
\text { pengemudi } \\
\text { sepeda motor }\end{array}$ & $\begin{array}{l}\text { - } \text { Demografi: usia } \\
\text { - Skala perusahaan } \\
\text { - Pengalaman kerja } \\
\text { - Pengalaman kecelakaan } \\
\text { - Lingkungan (Tipe Jalan, Cuaca, Waktu) } \\
\text { - Perilaku berkendara: TSV }\end{array}$ & $\begin{array}{l}\text { Hasil penelitian menunjukkan bahwa kecelakaan banyak } \\
\text { terjadi pada kurir yang memiliki pengalaman kerja kurang } \\
\text { dari } 6 \text { bulan. Selain itu pelanggaran terhadap sinyal lalu } \\
\text { lintas banyak dilakukan oleh kurir sepeda motor yang } \\
\text { bekerja di perusahaan skala kecil ( }<5 \text { pegawai), memiliki } \\
\text { pengalaman kerja kurang dari } 6 \text { bulan }(13,9 \%) \text {, terjadi } \\
\text { pada cuaca berawan dan cerah }(12,4 \%) \text {, terjadi di } \\
\text { persimpangan jalan }(29,8 \%) \text {, melibatkan kendaraan lain } \\
(31,2 \%) \text { dan terdapat kematian }(35,7 \%) \text {. }\end{array}$ \\
\hline
\end{tabular}

\begin{tabular}{lllll}
\hline (Pius dkk., Untuk mengetahui & Cross- & Sampel & Demografi: usia, jenis kelamin, tingkat & Hasil penelitian menunjukkan bahwa lebih dari setengah
\end{tabular}




\begin{tabular}{|c|c|c|c|c|c|}
\hline $\begin{array}{c}\text { Penulis/ } \\
\text { Negara }\end{array}$ & Tujuan Penelitian & $\begin{array}{c}\text { Desain } \\
\text { Penelitian }\end{array}$ & $\begin{array}{c}\text { Sampel } \\
\text { Penelitian }\end{array}$ & Variabel & Hasil Penelitian \\
\hline 2018)/Kenya & $\begin{array}{l}\text { determinan } \\
\text { karakteristik } \\
\text { individu, lingkungan } \\
\text { dan faktor manusia } \\
\text { yang berhubungan } \\
\text { dengan kejadian } \\
\text { kecelakaan dan } \\
\text { cedera pada } \\
\text { pengemudi sepeda } \\
\text { motor komersial }\end{array}$ & sectional & $\begin{array}{l}\text { penelitian } \\
\text { merupakan197 } \\
\text { sepeda motor } \\
\text { komersial }\end{array}$ & $\begin{array}{ll} & \text { pendidikan, status Pernikahan } \\
\text { - } & \text { Lingkungan: cuaca, kondisi jalan } \\
\text { - } & \text { Pengalaman Kecelakaan } \\
\text { - } & \text { Pengalaman Mengemudi } \\
\text { - } & \text { Pengalaman Pelatihan } \\
\text { - } & \text { Tipe dan kondisi motor } \\
\text { - } & \text { Frekuensi perawatan motor } \\
\text { - } & \text { Kebiasaan minum alkohol dan } \\
& \text { penyalahgunaan obat } \\
\text { - } & \text { Perilaku berkendara: ADU, RO, SPD, } \\
& \text { XPBL }\end{array}$ & $\begin{array}{l}\text { responden ( } 59 \%) \text { tidak pernah mengikuti pelatihan formal } \\
\text { terkait mengemudi dan } 35 \% \text { responden memiliki } \\
\text { pengalaman mengemudi selama satu tahun. } 80 \% \\
\text { responden pernah mengalami kecelakaan. Penyalahgunaan } \\
\text { obat ( } 20 \% \text { ) dan SPD ( } 36 \% \text { ) merupakan faktor manusia } \\
\text { yang paling banyak berhubungan dengan kejadian cedera } \\
\text { karena kecelakaan sepeda motor. }\end{array}$ \\
\hline $\begin{array}{l}\text { (Wu dan Loo, } \\
\text { 2015)/China }\end{array}$ & $\begin{array}{l}\text { Untuk mengetahui } \\
\text { karakteristik } \\
\text { pengemudi sepeda } \\
\text { motor, } \\
\text { menginvestigasi } \\
\text { risiko terhadap } \\
\text { keselamatan jalan } \\
\text { dan menyediakan } \\
\text { rekomendasi untuk } \\
\text { meminimalisasi risiko } \\
\text { tersebut. }\end{array}$ & $\begin{array}{l}\text { Cross- } \\
\text { sectional }\end{array}$ & $\begin{array}{l}\text { Sampel } \\
\text { penelitian } \\
\text { merupakan } 867 \\
\text { Pengemudi } \\
\text { Taksi Sepeda } \\
\text { Motor dan } 2029 \\
\text { Pengemudi } \\
\text { Sepeda Motor } \\
\text { Non-Okupasi }\end{array}$ & 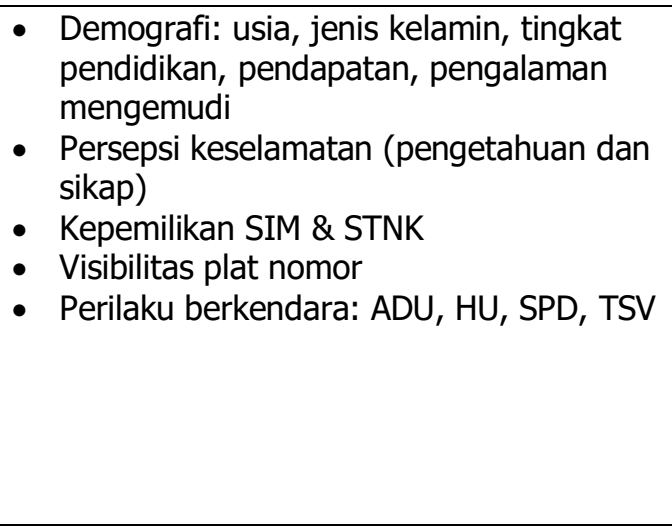 & $\begin{array}{l}\text { Hasil penelitian menunjukkan bahwa kedua kelompok } \\
\text { memiliki sikap yang buruk terhadap keselamatan jalan dan } \\
\text { memiliki perilaku berkendara yang tidak aman. Pengemudi } \\
\text { taksi sepeda motor memiliki risiko keselamatan jalan yang } \\
\text { lebih tinggi daripada pengendara sepeda motor non- } \\
\text { okupasi, seperti melaju dengan sangat cepat pada malam } \\
\text { dan pagi hari, mengabaikan penumpang yang tidak mau } \\
\text { menggunakan helm dan menerobos lampu lalu lintas. } \\
\text { Selain itu kepemilikan SIM dan STNK menjadi prediktor } \\
\text { yang signifikan terhadap perilaku tidak aman dalam } \\
\text { berkendara. Diperlukan peningkatan edukasi keselamatan } \\
\text { jalan dan penguatan terhadap peraturan kepemilikan SIM } \\
\text { dan STNK pada pengendara sepeda motor. }\end{array}$ \\
\hline $\begin{array}{l}\text { (Gboyega } \\
\text { dkk., } \\
\text { 2012)/Nigeria }\end{array}$ & $\begin{array}{l}\text { Untuk mengetahui } \\
\text { faktor yang } \\
\text { mempengaruhi } \\
\text { kecelakaan pada } \\
\text { pengemudi sepeda } \\
\text { motor komersial }\end{array}$ & $\begin{array}{l}\text { Cross- } \\
\text { sectional }\end{array}$ & $\begin{array}{l}\text { Sampel } \\
\text { penelitian } \\
\text { merupakan } 450 \\
\text { pengemudi } \\
\text { sepeda motor } \\
\text { komersial }\end{array}$ & 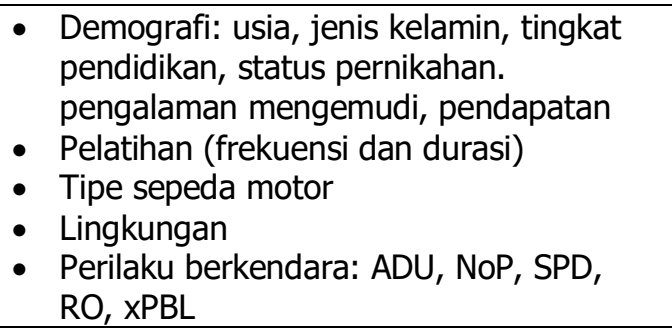 & $\begin{array}{l}\text { Hasil penelitian menunjukkan bahwa faktor demografi } \\
\text { memiliki pengaruh yang signifikan terhadap kejadian } \\
\text { kecelakaan pada pengemudi sepeda motor komersial. } \\
\text { Faktor yang secara signifikan berkontribusi untuk } \\
\text { meningkatkan tingkat kecelakaan pada sepeda motor } \\
\text { komersial adalah SPD, RO, jalan rusak, kerusakan mekanik, } \\
\text { ADU, dll. Ditemukan bahwa pengemudi sepeda motor } \\
\text { komersial tidak mematuhi Kode Keselamatan Jalan. }\end{array}$ \\
\hline
\end{tabular}

Ahmad Afif Mauludi, Zulkifli Djunaidi, Luthfi Saiful Arif 


\section{Pembahasan}

Kecelakaan lalu lintas memiliki kaitan yang erat dengan faktor perilaku berisiko yang dilakukan oleh pengemudi sangat mengemudikan kendaraan (Shinar, 2017). Perilaku berisiko dapat diklasifikasikan menjadi dua macam, yaitu kesalahan (error) dan pelanggaran (violation). Dimana kesalahan cenderung tidak dipengaruhi oleh intensi, sedangkan pelanggaran sangat dipengaruhi oleh intensi dari seorang individu dalam melakukan sesuatu (Reason, 2008). Penelitian ini mengkaji bagaimana perilaku berisiko saat berkendara, faktor-faktor yang mempengaruhinya dan bagaimana kontribusinya dalam kejadian kecelakaan lalu lintas pada pengemudi sepeda motor komersial dari berbagai penelitian. Berdasarkan penelitian terdahulu, perilaku berisiko pada saat berkendara dilakukan oleh sebagian besar (60\%) pengemudi sepeda motor komersial (Kiwango dkk., 2020). Perilaku berisiko yang dilakukan oleh pengemudi sepeda motor komersial tersebut memiliki hubungan yang signifikan dengan kejadian kecelakaan lalu lintas (Nguyen-Phuoc dkk., 2020a; Wankie dkk., 2021).

Perilaku menggunakan telepon genggam (52\%) merupakan perilaku berisiko yang paling sering dilakukan oleh pengemudi sepeda motor komersial berbasis aplikasi, diikuti dengan perilaku penggunaan indikator yang tidak sesuai $(31 \%)$, pelanggaran marka jalan $(25 \%)$, pelanggaran kecepatan $(21 \%)$, pelanggaran lampu lalu lintas (19\%) dan jumlah penumpang melebihi kapasitas $(17 \%)$. Perilaku berisiko saat mengemudi, berupa penggunaan indikator tidak sesuai, jumlah penumpang yang melebihi kapasitas, dan kebiasaan merokok memiliki hubungan yang signifikan dengan kejadian kecelakaan (Nguyen-Phuoc dkk., 2020a). Selain itu bentuk perilaku berisiko berupa berkendara dengan sangat cepat, menyalip dengan berbahaya dan konsumsi alkohol atau obat juga memiliki kontribusi signifikan terhadap peningkatan kecelakaan (Gboyega dkk., 2012). Berdasarkan salah satu studi, frekuensi penggunaan telepon genggam pada saat mengemudi memiliki hubungan dengan sikap dan kepercayaan serta persepsi risiko. Pengemudi yang sering menggunakan telepon genggam saat mengemudi, memiliki kepercayaan bahwa penggunaan telepon genggam saat mengemudi tidak memiliki pengaruh yang signifikan terhadap keselamatan berkendara dan memiliki persepsi bahwa melakukan hal tersebut tidak akan menyebabkan dirinya terlibat dalam kecelakaan lalu lintas (Nguyen-Phuoc dkk., 2020c). Berdasarkan data, perilaku terdistraksi pada saat berkendara termasuk penggunaan handphone, menyebabkan 3142 kematian di Amerika tahun 2019 (NHTSA, 2021) dan mulai tahun 2020 penggunaan handphone tanpa menggunakan handsfree pada saat berkendara dilarang di 24 negara bagian serta mengirim pesan singkat saat berkendara dilarang di 48 negara bagian Amerika (III, 2021).

Perilaku penggunaan indikator untuk berbelok yang tidak tepat juga memiliki hubungan yang signifikan dengan kecelakaan (Nguyen-Phuoc dkk., 2020a). Penggunaan indikator untuk berbelok yang tidak tepat, dapat menyebabkan lebih dari satu juta kasus kecelakaan yang menyebabkan meninggalnya ribuan pengemudi per tahun di Amerika (Ponziani, 2012). Berdasarkan penelitian lainnya, penggunaan lampu indikator dapat dipengaruhi oleh arah berbelok, tipe kendaraan, kepadatan lalu lintas, waktu berkendara, marka jalan dan tipe persimpangan (Faw, 2013). Penggunaan lampu indikator 
yang tepat dapat secara positif meningkatkan komunikasi dan keselamatan berkendara (Nguyen-Phuoc dkk., 2019). Selain lampu indikator, terdapat bukti bahwa penggunaan lampu depan sepeda motor, memiliki hubungan dengan kecelakaan. Penggunaan lampu tersebut dapat meningkatkan kewaspadaan pengemudi lainnya. Pada beberapa penelitian ditemukan bahwa penggunaan lampu depan sepeda motor, baik pada malam hari maupun siang hari, dapat menyebabkan sepeda motor lebih mencolok daripada lingkungan sekitarnya dan dapat mengurangi angka kecelakaan (Davoodi dan Hossayni, 2015; Shaheed dkk., 2011). Namun sebaliknya, dalam sebuah penelitian lainnya menunjukkan bahwa tidak ada hubungan antara penggunaan lampu sepeda motor dengan kejadian kecelakaan, baik pada malam hari maupun siang hari (Vissoci dkk., 2020). Perilaku berisiko selanjutnya adalah berkendara dengan penumpang lebih dari satu. Umumnya pengemudi sepeda motor komersial tidak diperbolehkan untuk membawa penumpang lebih dari satu, namun terdapat beberapa kondisi untuk melakukan hal tersebut, misalnya membawa saat penumpang membawa anaknya (Nguyen-Phuoc dkk., 2020a). Hal ini umumnya ditemukan pada negara dengan pendapatan rendah dan menengah (Schlottmann dkk., 2017). Pengemudi sepeda motor komersial yang membawa penumpang lebih dari satu, cenderung akan terlibat dalam kejadian kecelakaan daripada yang membawa hanya satu penumpang (Wankie dkk., 2021; NguyenPhuoc dkk., 2020a; Gboyega dkk., 2012). Walaupun memiliki risiko tinggi, praktik membawa lebih dari satu penumpang memiliki latar belakang ekonomi, sebagai usaha pengemudi sepeda motor dalam meningkatkan penghasilan mereka (Kiwango dkk., 2020).

Selain membawa penumpang lebih dari satu, perilaku merokok juga memiliki kecenderungan pengemudi untuk melakukan perilaku berisiko dan terlibat dalam kecelakaan. Pengemudi sepeda motor komersial yang memiliki kebiasaan merokok memiliki kecenderungan 2-3 kali lebih tinggi untuk tidak menggunakan helm saat berkendara dibandingkan yang tidak merokok. Perilaku berisiko saat mengemudi cenderung 9 kali lebih tinggi dilakukan oleh pengemudi yang memiliki kebiasaan merokok dan 18-19 kali lebih tinggi dilakukan oleh pengemudi yang memiliki kebiasaan minum alkohol (NguyenPhuoc dkk., 2020b). Pengemudi yang mengonsumsi minuman beralkohol memiliki kemungkinan 2-3 kali lebih tinggi mengalami kecelakaan parah tunggal, dibandingkan pengemudi yang tidak mengonsumsi alkohol (Wankie dkk., 2021). Selanjutnya, perilaku berisiko berkendara dengan sangat cepat pada malam dan pagi hari serta menerobos lampu lalu lintas, lebih tinggi menimbulkan risiko kecelakaan terhadap pengendara sepeda motor komersial, dibandingkan pengendara sepeda motor lain (Wu dan Loo, 2015). Namun secara keseluruhan, perilaku berisiko ditemukan lebih rendah pada pengemudi roda dua komersial berbasis aplikasi, dibanding pengemudi roda dua lainnya (Nguyen-Phuoc dkk., 2020a). Mengemudi dengan sangat cepat memiliki hubungan pada peningkatan 2-3 kali lebih tinggi kemungkinan terjadinya kejadian kecelakaan lalu lintas, dibandingkan pengemudi yang mengemudi dibawah batas kecepatan (Wankie dkk., 2021). Selain itu, pengemudi dengan durasi jam kerja yang tinggi ( $\geq 50$ jam per minggu) juga memiliki kecenderungan untuk melakukan perilaku berisiko, dibandingkan durasi jam kerja yang lebih rendah (Nguyen-Phuoc dkk., 2020a). 
Faktor demografi juga memiliki pengaruh yang signifikan terhadap kejadian kecelakaan pada pengemudi sepeda motor komersial (Gboyega dkk., 2012). Faktor demografi seperti umur, jenis kelamin dan tingkat pendidikan dapat mempengaruhi perilaku pengemudi dan meningkatkan angka kecelakaan lalu lintas pada pengemudi roda-dua (Kitamura dkk., 2018; Nguyen-Phuoc, 2020a; Pinchumpholsang, 2020). Pengemudi dibawah usia 30 tahun, memiliki kecenderungan untuk terlibat dalam kecelakaan lalu lintas dibandingkan pengemudi diatas usia 30 tahun (Nguyen-Phuoc, 2020a). Pengemudi dengan usia yang lebih muda memiliki kecenderungan untuk melakukan perilaku berisiko dengan memacu kendaraan dengan sangat cepat, menyalip dengan berbahaya, menerobos lampu merah, melanggar marka dan mengemudi dalam keadaan mabuk (Kitamura dkk., 2018; Nguyen-Phuoc, 2020a). Pengemudi sepeda motor komersial dengan jenis kelamin laki-laki lebih banyak ditemukan daripada pengemudi dengan jenis kelamin wanita (Nguyen-Phuoc, 2020a). Oleh karena itu, sebagian besar pengemudi sepeda motor yang mengalami kecelakaan dan mengalami kematian dialami oleh pria, dengan bentuk perilaku berisiko, yaitu mengemudi dengan kecepatan tinggi, mengemudi dalam keadaan mabuk dan menyalip secara berbahaya (Kitamura dkk., 2018). Pengemudi sepeda motor dengan tingkat pendidikan yang lebih tinggi memiliki kesadaran terkait dengan pengetahuan, peraturan, persepsi dan perilaku yang lebih baik, sehingga cenderung memiliki perilaku berisiko saat mengemudi yang lebih rendah dibandingkan pengemudi dengan tingkat pendidikan lebih rendah (Pinchumpholsang, 2020).

Pengalaman kecelakaan memiliki hubungan negatif yang signifikan dengan perilaku berisiko berkendara, dimana pengemudi yang memiliki pengalaman kecelakaan cenderung akan menggunakan helm dan tali dagu serta memiliki kepercayaan bahwa helm dan tali dagu dapat mengurangi risiko dari kecelakaan (Vissoci dkk., 2020). Faktor kepemilikan SIM dan STNK juga dapat menjadi prediktor yang signifikan terhadap perilaku berisiko saat berkendara (Wu dan Loo, 2015). Dimana pengemudi yang memiliki SIM dan STNK cenderung lebih sedikit melakukan perilaku yang berisiko dan memiliki tingkat persepsi risiko yang lebih tinggi (Pinchumpholsang, 2020). Persepsi terhadap bahaya yang ditimbulkan dari perilaku berisiko juga memiliki hubungan dengan perilaku berisiko yang dilakukan oleh pengemudi, dimana perilaku berisiko saat mengemudi lebih sering dilakukan oleh pengemudi yang memiliki persepsi risiko lebih rendah. Berdasarkan penelitian sebelumnya, pengemudi sepeda motor komersial memiliki persepsi yang tinggi bahwa menerobos lampu merah dapat membahayakan keselamatannya (Kiwango dkk., 2020). Persepsi yang tinggi tersebut menyebabkan pengemudi sepeda motor komersial lebih sedikit melakukan perilaku berisiko, dan lebih sedikit terlibat pada kecelakaan dibandingkan pengemudi sepeda motor lainnya (Nguyen-Phuoc dkk., 2020c). Perilaku berisiko saat mengemudi yang dapat menimbulkan kecelakaan juga memiliki hubungan dengan kecukupan pelatihan dan pengalaman mengemudi (Pius dkk., 2018). Pengemudi dengan pengalaman mengemudi lima tahun atau kurang memiliki kemungkinan mengalami kecelakaan lebih tinggi. Sebaliknya, pengemudi dengan pengalaman mengemudi lebih dari lima tahun memiliki kemampuan mengemudi yang lebih baik, sehingga dapat membantu meningkatkan keselamatan saat mengemudi 
(Wankie dkk., 2021). Oleh karena itu, untuk mengurangi tingkat kecelakaan pada pengemudi roda dua komersial, diperlukan penyediaan fasilitas peningkatan edukasi dan pelatihan keselamatan (Nguyen-Puhoc dkk., 2020a).

\section{SIMPULAN}

Berdasarkan hasil systematic review, didapatkan bentuk perilaku berisiko pengemudi sepeda motor saat berkendara yang signifikan berhubungan dengan kejadian kecelakaan yaitu, berkendara dalam pengaruh alkohol atau obat, merokok saat mengemudi, penggunaan lampu kendaraan yang tidak sesuai, penggunaan handphone saat mengemudi, jumlah penumpang yang melebihi kapasitas, pelanggaran marka jalan, menyalip secara berbahaya, penggunaan lampu indikator yang tidak sesuai, pelanggaran kecepatan serta pelanggaran rambu dan sinyal lalu lintas. Perilaku berisiko saat mengemudi tersebut dipengaruhi oleh berbagai faktor, yaitu umur, jenis kelamin, tingkat pendidikan, kepemilikan SIM \& STNK, persepsi terhadap keselamatan berkendara, pelatihan mengemudi, pengalaman mengemudi dan pengalaman kecelakaan. Secara umum, pengemudi sepeda motor komersial memiliki perilaku berisiko yang lebih sedikit daripada pengemudi sepeda motor lainnya. Untuk mengurangi tingkat kecelakaan pada pengemudi roda dua komersial, diperlukan penyediaan fasilitas peningkatan edukasi dan pelatihan keselamatan berkendara oleh pihak penyedia aplikasi atau pemerintah.

\section{UCAPAN TERIMA KASIH}

Ucapan terima kasih kepada Lembaga Pengelola Dana Pendidikan (LPDP) sebagai pihak yang telah mendanai proses studi peneliti.

\section{DAFTAR PUSTAKA}

Ali, M., Kharis, A. \& Karlina, D. (2018). Faktor-Faktor Yang Menjadi Pertimbangan Dalam Penggunaan Jasa Ojek Online (Go-Jek) Di Kota Mataram. Jurnal IImu Administrasi Publik FISIP UM Mataram, 6, 75-84.

BPS RI (2020). Statistik Transportasi Darat 2019.

Cooper, M. D. (1999). What is Behavioral Safety? Journal of Safety Research, 30, 309-328.

CRD (2009). Systematic Reviews: CRD's guidance for udertaking reviews in health care, University of York, Centre for Reviews and Dissemination.

Davoodi, S. R. \& Hossayni, S. M. (2015). Role of Motorcycle Running Lights in Reducing Motorcycle Crashes during Daytime; A Review of the Current Literature. Bulletin of Emergency \& Trauma, 3.

Djaleha, S. S. (2018). Penggunaan Sepeda Motor Sebagai Transportasi Komersial Menurut Undang-Undang Nomor 22 Tahun 2009 Tentang Lalu Lintas dan Angkutan Jalan. e-Journal Unsrat, 6, 100-105.

Fauziah, N. (2017). Ojek dari Masa ke Masa Kajian secara Manajemen Sumber Daya Manusia. Jurnal AKP, 7, 36-46.

Faw, H. W. (2013). To signal or not to signal: That should not be the question. Accident Analysis and Prevention, 59, 374-381.

Fishbein, M. \& Ajzen, I. (2011). Predicting and Changing Behavior The Reasoned Action Approach. Taylor \& Francis e-Library. 
Gboyega, A., Ebijuwa, A. S., Oyetola, S. O. \& Akinola, J. O. (2012). Factors influencing high rate of commercial motorcycle accidents in Nigeria. American International Journal of Contemporary Research 2, 130-140.

Gojek. (2021a). About Us [Online]. Tersedia di: https://www.gojek.com/about/ [Diakses pada 30 Januari 2021.

Gojek. (2021b). Products [Online]. Tersedia di: https://www.gojek.com/enid/products/ Diakses pada 20 Februari 2021].

Grab ID. (2021). Homepage [Online]. Tersedia di: https://www.grab.com/id/ Diakses pada 20 Februari 2021].

Heinrich, H. W. (1931). Industrial Accident Prevention, New York, McGraw-Hill, Inc.

III (2021). Facts + Statistics: Highway safety. Insurance Information Institute.

Kementerian Perhubungan. (2019). Peraturan Menteri Perhubungan Nomor 12

Tahun 2019 tentang Pelindungan Keselamatan Pengguna Sepeda Motor yang Digunakan Untuk Kepentingan Masyarakat. In: Perhubungan, K. (ed.).

Kitamura, Y., MakikoHayashi \& Yagi, E. (2018). Traffic problems in Southeast Asia featuring the case of Cambodia's traffic accidents involving motorcycles. IATSS Research, 42, 163-170.

Kiwango, G., Francis, F., Hasselberg, M., Chillo, O. \& Moshiro, C. (2020). Perception of unsafe driving behaviour and reported driving behaviour among commercial motorcyclists in Dar es Salaam, Tanzania. Transportation Research Part F: Traffic Psychology and Behaviour, 74, 30-39.

Konlan, K. D., Doat, A. R., Mohammed, I., Amoah, R. M., Saah, J. A., Konlan, K. D. \& Abdulai, J. A. (2020). Prevalence and Pattern of Road Traffic Accidents among Commercial Motorcyclists in the Central Tongu District, Ghana. Hindawi The Scientific World Journal.

Korlantas Polri (2019). Buku Potret Lalu Lintas di Indonesia tahun 2019.

Maze, J. R. (2019). The Meaning of Behaviour, Routledge.

Moher, D., Liberati, A., Tetzlaff, J., Altman, D. G. \& The PRISMA Group (2009).

Preferred Reporting Items for Systematic Reviews and Meta-Analyses:

The PRISMA Statement. Plos Medicine, 6.

Nguyen-Phuoc, D. Q., Gruyter, C. D., Nguyen, H. A., Nguyen, T. \& Su, D. N. (2020a). Risky behaviours associated with traffic crashes among appbased motorcycle taxi drivers in Vietnam. Transportation Research Part F: Traffic Psychology and Behaviour, 70, 249-259.

Nguyen-Phuoc, D. Q., Oviedo-Trespalacios, O., Nguyen, T. \& Su, D. N. (2020b). The effects of unhealthy lifestyle behaviours on risky riding behaviours A study on app-based motorcycle taxi riders in Vietnam. Journal of Transport \& Health, 16.

Nguyen-Phuoc, D. Q., Oviedo-Trespalacios, O., Sue, D. N., Gruyterf, C. D. \& Nguyen, T. (2020c). Mobile phone use among car drivers and motorcycle riders: The effect of problematic mobile phone use, attitudes, beliefs and perceived risk. Accident Analysis and Prevention, 143, 1-13.

Nguyen-Phuoc, D. Q., PhuongTran, A. T., Gruyter, C. D., Kim, I. \& Su, D. N. (2019). Turn signal use among car drivers and motorcyclists at intersections: a case study of Da Nang, Vietnam. Accident Analysis \& Prevention, 25-31. 
NHTSA. (2021). Distracted Driving [Online]. National Highway Traffic Safety Admnistration. Tersedia di: https://www.nhtsa.gov/riskydriving/distracted-driving Diakses pada 24 Maret 2021].

Oktopianto, Y., Shofiah, S., Rokhman, F. A., \& Pangestu, K. (2021). Analisis Daerah Rawan Kecelakaan ( Black Site ) Dan Titik Rawan Kecelakaan ( Black Spot ) Provinsi Lampung. Borneo Engineering: Jurnal Teknik Sipil, 5(1), 40-51. https://doi.org/10.35334/be.v5i1.1777

Pinchumpholsang, W. (2020). Study to Driving Behavior of Motorcycle Safety in the City of Ratchaburi Province, Thailand. RMUTT Global Business Accounting and Finance Review, 4, 41-52.

Pius, W., Wilberforce, C., Wepukhulu, M. \& Victor, M. (2018). Determinants of Commercial Motorcycle Related Injuries In Butula Subcounty, Busia County, Kenya. IOSR Journal of Nursing and Health Science, 7, 47-59.

Ponziani, R. (2012). Ponziani, R. (2012). Turn Signal Usage Rate Results: A Comprehensive Field Study of 12,000 Observed Turning Vehicles. SAE Technical Paper Series.

Reason, J. (2008). The Human Contribution Unsafe Acts, Accidents and Heroic Recoveries, London, CRC Press.

Schlottmann, F., Tyson, A. F., Cairns, B. A., Varela, C. \& Charles, A. G. (2017). Road traffic collisions in Malawi: Trends and patterns of mortality on scene. Malawi Medical Journal, 29, 301-305.

Shaheed, M. S. B., Zhang, W., Gkritza, K. \& Hans, Z. (2011). Differences in Motorcycle Conspicuity-related Factors and Motorcycle Crash Severities in Daylight and Dark Conditions. the 3rd International Conference on Road Safety and Simulation. Indianapolis, USA.

Shin, D. S., Byun, J. H. \& Jeong, B. Y. (2018). Crashes and Traffic Signal Violations Caused by Commercial Motorcycle Couriers. Safety and Health at Work, 10, 213-218.

Shinar, D. (2017). Traffic Safety and Human Behavior. 2nd ed. Bingley: Emerald Publishing.

Siddaway, A. P., Wood, A. M. \& Hedges, L. V. (2018). How to Do a Systematic Review: A Best Practice Guide for Conducting and Reporting Narrative Reviews, Meta-Analyses, and Meta-Syntheses. The Annual Review of Psychology, 70, 747-770.

Vissoci, J. R. N., Krebs, E., Meier, B., Fiorese, I., Vieira, L. d. A., Byiringiro, F., Rulisa, S. \& Staton, C. A. (2020). Road traffic crash experience among commercial motorcyclists in Kigali, Rwanda. International Journal of Injury Control and Safety Promotion, 181-187.

Wankie, C., Al-Delaimy, W., Stockman, J., Alcaraz, J., Shaffer, R. \& Hill, L. (2021). Prevalence of crashes and associated factors among commercial motorcycle riders in Bamenda, Cameroon. Journal of Transport \& Health.

WHO (2018). Global Status Report on Road Safety 2018.

Wicaksono, P. E. (2019). Rawan Kecelakaan, Menhub Ingin Pengemudi Ojek Online dapat Asuransi. Liputan6.

Wu, C. Y. H. \& Loo, B. P. Y. (2015). Motorcycle safety among motorcycle taxi drivers and non-occupational motorcyclists in developing countries: A case study of Maoming, South China. Traffic Injury Prevention, 17, 170175. 